\title{
A New Approach to Decision Prioritization - Case for Healthcare Decision-Makers
}

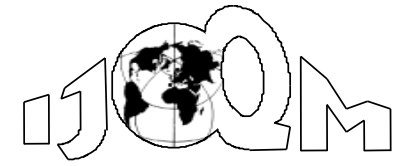

Volume 25, Number 4

December 2019, pp. 275-297
Sudhanshu Singh

Rakesh Verma

National Institute of Industrial Engineering

(ssingh11@gmail.com)

(rakeshverma@nitie.ac.in)

Saroj Koul

OP Jindal Global University

(skoul@jgu.edu.in)

Decisions are guided by data and concerns (issues) that may recur as per the situation. While there is a growing literature on data-driven decision-making, the linkages of data to issues are not explicit, especially in the healthcare environment. Based on the established root cause analysis models, the attempt here is to develop an integrated framework for the visual, hierarchical and quantitative representation of the different causal relationships. A framework so designed demonstrates the interplay of data and issue(s). The issue(s) identified from the literature and actual issue(s) raised in the healthcare environment are exhibited as an Effect-Why diagram with probabilities analyzed using Markov chain in Lindol8 software. Last, of all, the network diagram (and its associated table) show a comprehensive inter-relationships and provide details on the Effect-Why diagram for understanding decision-making. The Markov chain illustrates the issues that are expected to be seen in the long term. This framework shall be useful for any organization attempting the identification and resolution of root issues, in their journey towards excellence.

Keywords: Issues Complexity, Causal Relationships, Effect-Why Diagram, Markov Chain, Decision-Framework

\section{Introduction}

Humans distinguish themselves from other species by the fact that they can talk about, read, write, fight, or adjust when dealing with issues, which, essentially, are the points of debate and contention. Issues are typically formulated in the form of statements or queries such as "What is the issue here?"; "Why is this an issue?"; "Who is causing the issue?"; "Can this issue be resolved?"; "Who can resolve this issue?"; "Tell me the key issues"; "Are these the only issues?". Organizational discussions and deliberations are centered around issues. The type and frequency of issues vary per an organization's situation. The memories of our experiences with managing our issues may sometimes last over a lifetime.

Issues cause events. Events happen over a period of time and play a major role in giving shape to how we think, feel and act (Morgeson et al., 2015). Some are selfevident, whereas others may require to be deduced from the content. An unmet need or want can create issue (s). Finding the right issues that reflect the customer needs and demands can lead to invention and creation of new business models. 
The willingness and ability to deal with issues, whether faced individually or collectively, varies. The quest for excellence requires the use of appropriate framework(s) and tools to identify and resolve issues. Data can identify issues and issues may need data for their validation and need for resolution. Several methodologies (EFQM and MBNQA) exist in the literature for organizational excellence. There are interlink ages between activities, outcomes and the behaviors (Jagoda et al., 2013). The issues need to be both known and logically connected. Their cause and effects also need to be quantifiable, as shown by the applications for determining the root issues.

\section{Literature Review}

There is an increasing trend towards generating insights from data by the use of various analytical tools and algorithms. Any insight from data is expected to bring the decision-maker closer to the resolution of issue(s).

The authors have reviewed existing literature to gain an understanding of how words such as problems, issues, difficulties, challenges, constraints, gaps, bottlenecks are used while describing the current state of an organization. Sometimes the requirements for the future such as what is emphasized, needed or desired, potential/required improvement, indicators or anything denoting desirability are taken as a negative for the issue(s). At the core of experience are the events that we face in our personal and work lives (Morgeson et al., 2015).

The healthcare sector has seen various applications of operations research. The effect of prioritization of patients on the operating room scheduling has been studied for elective surgeries (Oliveira et al., 2019). Uriarte et al. (2017) have used an integrated approach covering simulation, optimization and data mining for making improvements in an emergency department. In the following section, decisionmaking and the interrelationships among data, issues and decisions with an example of the healthcare sector is demonstrated.

\subsection{Decision and Decision-Making}

Decision making is the primary duty of any manager (Nooraie, 2008) and aims to resolve one issue or other. The outcome of a single decision can lead to multiple effects (Nutt, 2001) and is not measurable by a single metric. The objectives, alternatives and risks are three critical aspects of any decision (Schwarber, 2005) that are investigated by decision-makers.

Figure 1 classifies decision as strategic, operational, tactical or neo-strategic based upon the scope of the firm and required commitment (Shivakumar, 2014).

\begin{tabular}{|l|l|l|l|}
\hline \multirow{4}{*}{ Scope of the firm } & \multicolumn{2}{|c|}{ Commitment } \\
\cline { 2 - 4 } & & Significant Changes & Insignificant Changes \\
\cline { 2 - 4 } & $\begin{array}{l}\text { Significant Changes } \\
\text { Insignificant Changes }\end{array}$ & Strategic & Neo-strategic \\
\cline { 3 - 4 } & Tactical & Operational \\
\hline
\end{tabular}

Figure 1 Scope and Commitment of the Firm [Source: (Shivakumar, 2014)]

The field of multiple criteria decision analysis (MCDA) is concerned with making decisions based upon the criteria and alternatives. Diaby et al. (2013) have carried out a bibliometric analysis of articles on MCDA from 1960 to 2011 wherein they 
find healthcare systems encounter challenges related to rationality and transparency in decision making. Reddy et al., (2019) through MCDA showcase public health recommendations at the National Institute for Health and Care (NICE), UK.

\subsection{Issues}

Issues are shaped and given a unique place by the culture where they are visible. A non-issue for one in some organization may be a big issue for another in a different organization. Some issues remain within an organizational boundary, while some issues accompany the persons wherever a person of influence moves. A few definitions of issues (Singh et al., 2017) taken as a verb and a noun are as:

Verb: "Result or be derived from."; "Come, go, or flow out from."

Noun: "An important topic or problem for debate or discussion."; "A result or outcome of something."

\subsection{Perceptions and Issues}

Decision-makers go through a learning curve to gain experience and expertise based upon the time they spent on doing their work activities. They also develop an increased understanding of the issues around them as well as perceiving things in specific ways. Issues are concepts that come in various forms and can exist in different places. Issues cause as well as get affected by perceptions. Perceptions are also the results of issues. They can affect the behaviors and performance of the task(s). For example, a patient's undesirable perception about the quality of care at a particular tertiary hospital could lead to the issue of lack of trust in the diagnostic results and seeking the second opinion from another hospital.

In some cases, these perceptions could be limited to particular specialties within the hospital wherein the issues of trust vary from specialty to specialty. Similarly, any issues of concern, such as those related to incorrect coding (Ewing, 2016) could be handled in simple ways. The design and deployment of web-based systems, supported by analytics and reporting capabilities, can provide means to solve issues.

\subsection{Issues as Streams}

The issues can be seen to flow like a stream to be moving from one place to another (Langley et al.,1995) wherein they are seen to continue in one form or other for a considerable period and do not disappear after making critical decisions. People may start accepting issues as a given in their work environment and therefore plan and organize their tasks taking cognizance of the same. Many issues flow on and have an intersection with other issues (Langley et al.,1995).

\subsection{Issues as a Markov Chain}

Issues may have dynamic linkages too. The authors view the issues as following a Markov decision process and forming a Markov chain. A number of studies have been carried out in various areas regarding the use of Markov decision process and Markov chain. Markov decision process is used for increasing patient flow efficiency between the other units of a hospital and its emergency department (Gonzalez, 2018). A model of the renewal process is developed using a Markov process for evaluation of inter-day hospital appointment plans and designing better rules of appointment, particularly those having resources that are either limited or insufficient (Song et al., 2018). 


\subsection{Issues in the Healthcare Context}

Patients visit hospitals for healthcare wherein they generally receive care from multiple providers (Almoaber and Amyot, 2017) due to reasons such as mobility requirements and availability of the services. This can lead to their medical records being incomplete and/or spilt across locations. The data can also differ in the way it is maintained across organizations and languages. It is generally recognized that there are asymmetric knowledge and sharing of information (Berland, 2017) between the patients and the healthcare providers. There may be some difference in factors considered important in developing countries versus developed countries. The World Health Organization focuses on quality, efficacy, policy and safety (Brooks, 2013) in its global strategy for both the traditional and the alternative medicine.

During the process of delivery of healthcare services, there is some personal and some shared understanding between the providers and the healthcare seekers. A Johari Window developed by Luft and Ingham to form a two-by-two table of things of "things that providers know" and "things that patients know" as adapted from Berland (2017) is at Figure 2.

\begin{tabular}{|l|l|l|}
\hline & \multicolumn{2}{|c|}{ Things that patients know } \\
\hline \multirow{2}{*}{$\begin{array}{l}\text { Things that providers } \\
\text { know }\end{array}$} & $\begin{array}{l}\text { Things that both patients and } \\
\text { providers know }\end{array}$ & Things that only patients know \\
\cline { 2 - 3 } & Things that only providers know & $\begin{array}{l}\text { Things that neither patients nor } \\
\text { providers know }\end{array}$ \\
\hline
\end{tabular}

Figure 2 Things Providers Know Versus Patient Know [Adapted from (Berland, 2017)]

As can be seen, a healthcare provider neither knows nor is expected to know all the things that are beneficial for the patients. This lack of knowledge may lead to issues for the patient and attempts to mitigate the risk by reaching out to the providers whom they think are best qualified to provide the healthcare interventions.

The presence of issues can be deduced from literature by the grouping of some words. These different and unique terms are a group of words one can look closely at for identifying the issues. Table 1demonstrates a sample list of word groups or statements with some level of rephrasing in some cases to bring more clarity. An issue could be derived from these statements, such as 'staffing levels' could mean an issue of insufficient staffing for the work requirement. Similarly, the mention of 'communication effectiveness could imply that the issue of 'communication is ineffective'.

The process of combing the sentences and paragraphs for issues can bring out some insights on what and where these issues are present.

\subsection{Interlink ages of Decision and Issues}

Decisions are linked to each other (Langley et al., 1995) in sequential, lateral and percussive ways. The condition that a decision-maker faces while deciding (Nutt, 2001) influences its success. These decisions interlink ages may be about the same issue but at different times, concurrently viewing links between different issues and links showing the decisions (Langley et al., 1995) on one issue affecting other issues (Annexure 1).

During the process of decision-making, the decisions makers either make optimizing or satisficing decisions based on the contextual requirements. Any 
decision on issue(s) leads to the task(s) being performed, event(s) getting happened and behavioral change. For example, the decision to set up a Centre of Excellence would entail tasks such as preparing a project plan, hiring resources and outsourcing of specific work supplemented with the behavior requirements changing to the management of projects from the operations focused mindset till it is set up.

Table 1 Sample List of Issues Taken or Deduced from the Literature

\begin{tabular}{|c|c|}
\hline Issue(s) from the research literature & Authors \\
\hline $\begin{array}{l}\text { Event-related to infection; qualification of staff; staffing levels; information } \\
\text { management; communication effectiveness; appropriateness of physical } \\
\text { environment; identification of environmental risks; nursing error; doctor's } \\
\text { error; poor work environment; wrong medication; the incorrect amount of } \\
\text { medication; incorrect diagnosis; and doctors' instructions incorrectly } \\
\text { interpreted. }\end{array}$ & $\begin{array}{l}\text { (Dhillon, } \\
\text { 2003) }\end{array}$ \\
\hline $\begin{array}{l}\text { Use of coding systems; method of coding; notes on the use cases; variances } \\
\text { among the information systems; average severity score; a procedure not } \\
\text { carried out; different definitions of patient events; case mix varying across } \\
\text { comparative hospitals; length of stay. }\end{array}$ & (Booth, 2005) \\
\hline $\begin{array}{l}\text { Overall quality of care; customized care driven by patient needs and values; } \\
\text { increase consumers' engagement with their healthcare; providing greater } \\
\text { control to patients over their health care decisions; better communication; } \\
\text { sharing of information; increased transparency with patients; accessing the } \\
\text { medical information; handling the administrative issues electronically; } \\
\text { enhancing efficiency of communication between patient and provider; } \\
\text { increasing delivery of clinical interventions; health outcomes; provision of } \\
\text { electronic access to healthcare information; privacy and security; "digital } \\
\text { divide" between regular and inexperienced users of internet. }\end{array}$ & $\begin{array}{l}\text { (Patel et al., } \\
\text { 2011) }\end{array}$ \\
\hline $\begin{array}{l}\text { Unplanned readmissions; hospital performance; quality of hospital care; } \\
\text { patients' perspectives on inpatient care; perceptions on skill; responsiveness } \\
\text { of nurses and physicians; responsiveness to preferences of patients' } \\
\text { requirements and values; association of excellent communication to higher } \\
\text { patient satisfaction; overall satisfaction score; interaction quality with } \\
\text { hospital personnel; perception of discharge process; discharge planning; } \\
\text { experiencing better health outcomes. }\end{array}$ & $\begin{array}{l}\text { (Boulding et } \\
\text { al., 2011) }\end{array}$ \\
\hline $\begin{array}{l}\text { Delivering safe care; high quality of care; transparency in care; care being } \\
\text { accountable; efficiency in care; inadequate information; limited hospital } \\
\text { resource; shortages of qualified operating room staff; utilization of the } \\
\text { operating room; trust and confidentiality; react with suspicion; the amount } \\
\text { of resistance; incorrect interpretation; and knowledge sharing. }\end{array}$ & $\begin{array}{l}\text { (Van Veen-B, } \\
\text { 2016) }\end{array}$ \\
\hline $\begin{array}{l}\text { Such as ethical and legal issues; barriers to access; healthcare coverage; } \\
\text { delays between warnings and action; overrepresentation; regional diversity; } \\
\text { conflict of interests; lower participation; unavailability; and irresponsibility. }\end{array}$ & (Silva, 2018) \\
\hline $\begin{array}{l}\text { People unaware of their errors; error-free setups; surgeries getting done } \\
\text { later; reduced usage of valued resources; unreliable supply system; nurses } \\
\text { stashing the tools they need; supplies exceeding the expiry date; electronic } \\
\text { tagging of goods; key person is busy or missing; human resources } \\
\text { commonly go underused; chaotic supply areas; needed skills missing; and, } \\
\text { time to care. }\end{array}$ & $\begin{array}{l}\text { (Schonberger, } \\
2018 \text { ) }\end{array}$ \\
\hline
\end{tabular}




\section{Integrating Data and Issue Based Decision-Making}

In this section, the concepts of issue-based-decision-making (IBDM) along with data-driven-decision-making (DDDM) are first explained, followed by their linking in the proposed Data-Issue-Decision-making (DID) Framework. A few examples regarding the complexity of interactions for the seemingly straightforward issues are presented through the suggested MEVACTRIBEF network diagram and its MEVACTRIBEF Table.

\subsection{Issue-Based Decision-Making (IBDM)}

During any work activity, there may be situations that are perceived to be undesirable. These could be a perception of things not going as planned. Any shortfall from expected outputs and outcomes could point to some issue(s). The relationship between the issue and the issue-based decision is at Table 2 with some demonstrative examples.

Table 2 Issue and Issue-Based Decisions

\begin{tabular}{|c|c|}
\hline Issue & Issue-based decision \\
\hline Unable to decide which project to select & $\begin{array}{l}\text { Utilize Effect-Why diagram for separating causes that have } \\
\text { many effects to those having fewer effects. } \\
\text { Markov chain analysis for quantifying the visible effects. } \\
\text { Multi-criteria decision-making for prioritizing the solution } \\
\text { requirements. }\end{array}$ \\
\hline $\begin{array}{l}\text { Which issues to prioritize for } \\
\text { improvement }\end{array}$ & $\begin{array}{l}\text { Utilize Effect-Why diagram and issue complexity table to } \\
\text { enhance understanding and priorities }\end{array}$ \\
\hline Lack of awareness and training & $\begin{array}{l}\text { Conducting training programs } \\
\text { Developing shared knowledge repositories }\end{array}$ \\
\hline $\begin{array}{l}\text { Limited understanding of customer } \\
\text { requirements }\end{array}$ & Carry out market research \\
\hline $\begin{array}{l}\text { Unnecessary delays in the pre-operating } \\
\text { room }\end{array}$ & $\begin{array}{l}\text { Getting all data about patients available before the patient } \\
\text { leaves the ward }\end{array}$ \\
\hline
\end{tabular}

\subsection{Data-Driven Decision-Making (DDDM)}

Individuals and entities collect qualitative and quantitative data to measure progress concerning their objectives. Any process of data analysis for deriving insights may use tools to check sheets and charts to say applications of artificial intelligence and deep learning. In cases where data is vague or imprecise, applications, such as fuzzy logic, can be utilized, such as a data-driven method used to detect the bottleneck ( $\mathrm{Li}$ et al., 2009) on a production line in a manufacturing system. New business models can be generated by using data acquired internally and externally (Sorescu, 2017). A loss of cargo in logistics system (Wu et al., 2017) have been investigated using datadriven analytics. Healthcare sector has its unique sets of issues. Risks associated with the hospital-acquired falls (Lucero, 2018) have been studied by using a combination of approaches based on practices and data. The time taken by caregivers in a patient assignment (Yalcindag et al., 2016) problem is estimated using a data-driven method. Table 3 (overleaf) gives some illustrative examples of data-driven decisionmaking. Further, Table 4 compares DDDM with IBDM and shows that while they complement each other, they also aid in improved decision-making. 


\subsection{Data Issue Decision Framework}

Decision making is an ongoing process in the journey to organizational excellence. When people work on routine activities, they gradually become better in doing certain things and follow a learning curve. Along with gaining experience and expertise, they also build perceptions on what is happening around them, issues they may face during the course of performance and what to do about them in case they occur.

Table 3 Data and Data-Driven Decisions

\begin{tabular}{|l|l|}
\hline \multicolumn{1}{|c|}{ Data } & \multicolumn{1}{c|}{ Data-driven-decision } \\
\hline $\begin{array}{l}\text { Cost information on parts and } \\
\text { components }\end{array}$ & $\begin{array}{l}\text { Make or buy decisions } \\
\text { Pricing decisions }\end{array}$ \\
\hline $\begin{array}{l}\text { Location of factory, warehouses and } \\
\text { retailers }\end{array}$ & $\begin{array}{l}\text { Where to do what to maximize profits or minimize cost } \\
\text { Making decisions focused on satisficing when having } \\
\text { multiple objectives }\end{array}$ \\
\hline $\begin{array}{l}\text { Number of doctors, theatres, } \\
\text { patients, medical specialties }\end{array}$ & $\begin{array}{l}\text { Scheduling the flow of patients for increased utilization } \\
\text { Assignment decisions }\end{array}$ \\
\hline Process and value stream maps & Identification and resolving bottlenecks \\
\hline Event logs & $\begin{array}{l}\text { Process mining for discovering process, compliance and } \\
\text { replay. Identification and resolving bottlenecks }\end{array}$ \\
\hline
\end{tabular}

Table 4 Comparing Data-Driven-Decision-Making and Issue-Based-Decision-Making

\begin{tabular}{|l|l|}
\hline \multicolumn{1}{|c|}{ Data-driven-decision-making } & \multicolumn{1}{c|}{ Issue-based-decision-making } \\
\hline Data has an influence on decision & An Issue has an influence on decision \\
\hline Data is sought for making a decision & Issues are identified for making a decision \\
\hline $\begin{array}{l}\text { Data guides the process of identification } \\
\text { of issue(s) }\end{array}$ & Data sought for gaining an understanding of the issue \\
\hline $\begin{array}{l}\text { Utilize expertise in technologies and } \\
\text { applications for preparing and utilizing } \\
\text { data. }\end{array}$ & Requires domain expertise and experience \\
\hline $\begin{array}{l}\text { Application of tools and methods of } \\
\text { data mining, process mining, artificial } \\
\text { intelligence, deep learning, etc. }\end{array}$ & $\begin{array}{l}\text { Application of experience and expertise to generate } \\
\text { views for identifying and resolving issues using } \\
\text { methods such as Effect-Why diagram. }\end{array}$ \\
\hline $\begin{array}{l}\text { Requires experience and expertise to } \\
\text { benefit from data-driven decision- } \\
\text { making. }\end{array}$ & $\begin{array}{l}\text { Requires data and analysis results to support issue- } \\
\text { based decision-making. }\end{array}$ \\
\hline
\end{tabular}

Issues keep on repeating and get somehow managed based upon on past experiences on same or related issues. There is also increasing focus on everincreasing data and big data on account of volume, variety, velocity and veracity and which provides a decision-maker to identify and validate issues based upon what data speaks. According to the authors, many decision-makers are too busy carrying out firefighting activities and seldom put any disciplined effort in getting to the root issue(s) and finding a final solution. Many times, it is due to lack of awareness or training on using data to guide the decision-making process. Therefore, there is an urgent need to integrate data-driven decision making with the issue-based decision making for making relevant and timely decision(s) from a holistic perspective. 
An issue is a fundamental concept and the 'unit of analysis' (Langley et al., 1995) in the integrated Data Issue Decision (DID) Framework. It connects data, issue and decision. The DID Framework integrates DDDM and IBDM (and links among decisions and issues are in Table 9 of Annexure 1). Also, the Effect-Why diagram (Singh et al., 2017) compares well vis-à-vis other well-known tools for finding the root issue (Table 10 in Annexure 2).

The DID Framework provides a high-level understanding of the interconnection of issues, data and decisions. One may discover issues from data or collect data to validate the issues or perceptions or opinions. The Effect-Why diagram (unidirectional and multidirectional), MEVACTRIBEF network diagram, MEVACTRIBE table, issues complexity matrix and Markov chain are tools proposed for understanding the current state and projecting the future state. The authors explain these concepts and tools for understanding the current state and the same can be employed for setting the future states wherein some issues may disappear post their resolutions, and the probability values change. The DID Framework developed as in Figure 3 provides high-level visibility to managing change in any organization. Many of the issues that are observed in different organizations are documented in the existing literature and may validate in another organization. The issues in Table 1 then were discussed in a tertiary hospital for their validation. The applicable issues and actual issues faced were taken together for detailing.

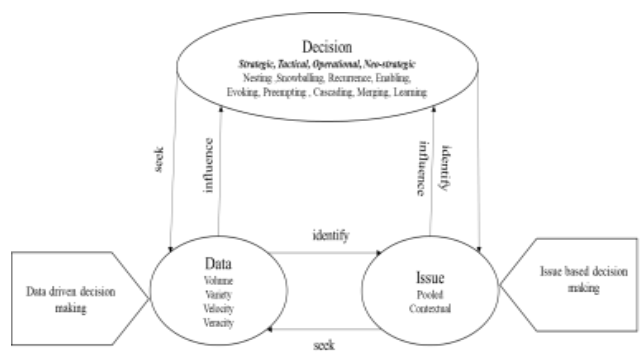

Figure 3 The DID Framework

\section{Method}

The main steps in issues identification and resolution process driven by the DID Framework are:

1. Identify and draw causal relationships among the issues in Effect-Why diagram

2. Develop a unidirectional Effect Why diagram for preliminary analysis

3. Decide and assign the probability values in the Effect-Why diagram

4. Prepare the issue complexity matrix for the unidirectional Effect Why diagram

5. Using Markov chain analysis calculate the steady-state probabilities of the issues

6. Gather data and populate the MEVACTRIBEF table for the understanding of the current state

7. Review and develop a multidirectional Effect Why diagram if needed

8. Review and place the probability values in the multidirectional Effect-Why diagram

9. Prepare the issue complexity matrix for the multidirectional Effect-Why diagram

10. Calculation of all the steady-state probabilities using Markov chain analysis 
11. Decide on the issues selection and resolution process and expected future state Effect-Why diagram, MEVACTRIBEF table, issue complexity matrix and the steady-state probabilities

12. Go back to Step 1 post improvement.

The use of the DID Framework is explained using the example of a tertiary hospital in India to demonstrate concepts and tools. The unidirectional issues linkages and the associated Effect-Why diagram is the first level of studies on issues and their relationships, taking only a single effect and connecting issues leading in a causal relationship as in Figure 4. The issues and results in the MEVACTRIBEF can be shown visually as cause-and-effect linkages using the Effect-Why diagram as in Figure 4 and Figure 5.

\subsection{Unidirectional Issues Linkages}

In unidirectional issues linkage, there is a sequential progression (with or without branching) from one or more issues to other linked issues. Annexure 2 lists several methods, including the root cause analysis, tree diagram, and Effect-Why diagram reflecting unidirectional linkages. The figure is read from the bottom, starting from the effect and move up to different levels of Why. The Why (W1) is to be read as the effect of Why (W2). The loop in effect (E1) value of 1 shows that this is a recurring effect (or issue). Communication is ineffective leads to recurring medical errors as well as decreasing trust, and the value of $1 / 2$ is placed to denote one cause leading to two effects. This number helps in enhancing the readability of the Effect-Why diagram wherein one can identify issues that are leading to more effects just by a glance.

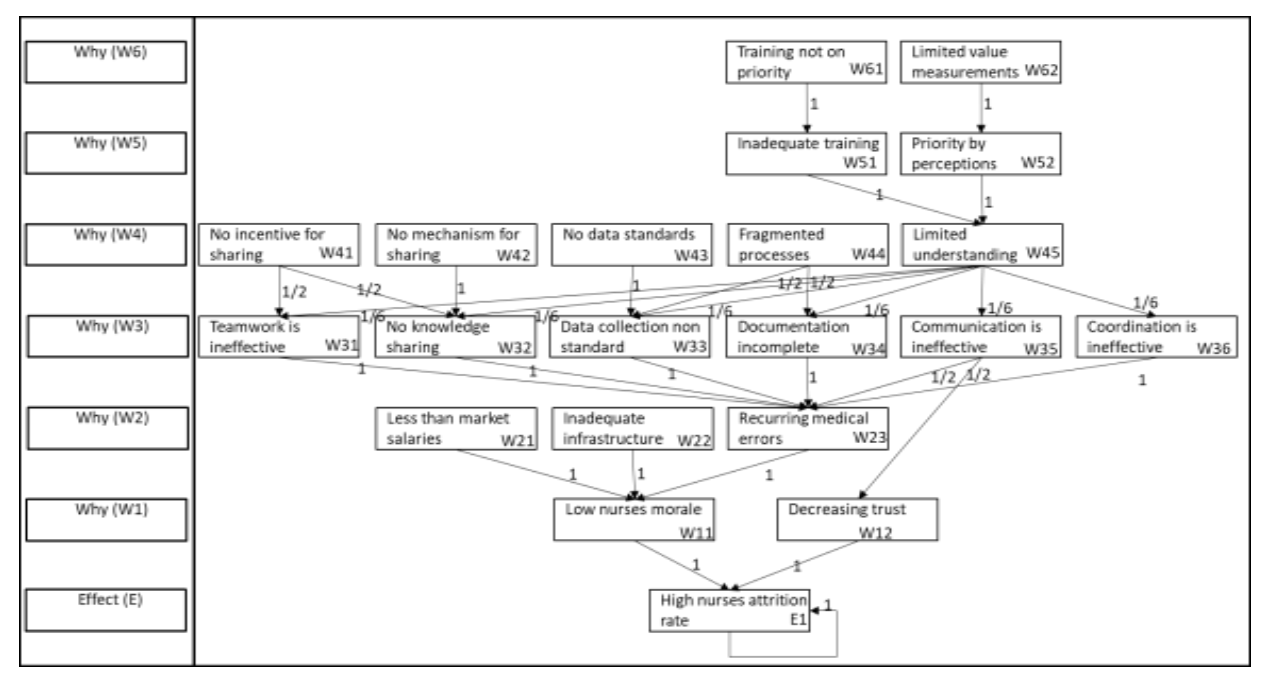

Figure 4 Unidirectional Effect-Why Diagram for a High Nurses' Attrition Rate

The issues complexity matrix arising from the interlink ages of issues in the Effect-Why diagram can be calculated from the issue complexity matrix as in Table 5. A value is One (1) is placed if there is a cause-effect linkage else we put 0 (Zero). 
Table 5 Issues Complexity Matrix for Unidirectional Effect-Why Diagram

\begin{tabular}{|c|c|c|c|c|c|c|c|c|c|c|c|c|c|c|c|c|c|c|c|c|c|c|}
\hline & $\begin{array}{l}\text { W- } \\
61\end{array}$ & $\begin{array}{l}W- \\
62\end{array}$ & $\begin{array}{l}\text { W- } \\
51\end{array}$ & $\begin{array}{l}\text { W- } \\
52\end{array}$ & $\begin{array}{l}\text { W- } \\
41\end{array}$ & $\begin{array}{l}\text { W- } \\
\mathbf{4 2}\end{array}$ & $\begin{array}{l}\text { W- } \\
\mathbf{4 3}\end{array}$ & $\begin{array}{l}W- \\
44\end{array}$ & $\begin{array}{l}\text { W- } \\
45\end{array}$ & $\begin{array}{l}\text { W- } \\
31\end{array}$ & \begin{tabular}{|l|} 
W- \\
32
\end{tabular} & $\begin{array}{l}\text { W- } \\
\mathbf{3 3} \\
\end{array}$ & $\begin{array}{l}\text { W- } \\
\mathbf{3 4}\end{array}$ & $\begin{array}{l}\text { W- } \\
\mathbf{3 5}\end{array}$ & $\begin{array}{l}\text { W- } \\
36\end{array}$ & $\begin{array}{l}\text { W } \\
21\end{array}$ & $\begin{array}{l}\mathrm{W} \\
22\end{array}$ & \begin{tabular}{|l} 
W \\
$\mathbf{2 3}$
\end{tabular} & $\begin{array}{l}\text { W- } \\
11\end{array}$ & $\begin{array}{l}\text { W- } \\
12\end{array}$ & \begin{tabular}{|c|}
$\mathbf{E}-$ \\
1
\end{tabular} & Tota \\
\hline-61 & 0 & 0 & 1 & 0 & 0 & 0 & 0 & 0 & 0 & 0 & 0 & 0 & 0 & 0 & 0 & 0 & 0 & 0 & 0 & 0 & 0 & 1 \\
\hline-62 & 0 & 0 & 0 & 1 & 0 & 0 & 0 & 0 & 0 & 0 & 0 & 0 & 0 & 0 & 0 & 0 & 0 & 0 & 0 & 0 & 0 & 1 \\
\hline-51 & 0 & 0 & 0 & 0 & 0 & 0 & 0 & 0 & 1 & 0 & 0 & 0 & 0 & 0 & 0 & 0 & 0 & 0 & 0 & 0 & 0 & 1 \\
\hline 52 & 0 & 0 & 0 & 0 & 0 & 0 & 0 & 0 & 1 & 0 & 0 & 0 & 0 & 0 & 0 & 0 & 0 & 0 & 0 & 0 & 0 & 1 \\
\hline-41 & 0 & 0 & 0 & 0 & 0 & 0 & 0 & 0 & 0 & 1 & 1 & 0 & 0 & 0 & 0 & 0 & 0 & 0 & 0 & 0 & 0 & 2 \\
\hline-42 & 0 & 0 & 0 & 0 & 0 & 0 & 0 & 0 & 0 & 0 & 1 & 0 & 0 & 0 & 0 & 0 & 0 & 0 & 0 & 0 & 0 & 1 \\
\hline-43 & 0 & 0 & 0 & 0 & 0 & 0 & 0 & 0 & 0 & 0 & 0 & 1 & 0 & 0 & 0 & 0 & 0 & 0 & 0 & 0 & 0 & 1 \\
\hline-44 & 0 & 0 & 0 & 0 & 0 & 0 & 0 & 0 & 0 & 0 & 0 & 1 & 1 & 0 & 0 & 0 & 0 & 0 & 0 & 0 & 0 & 2 \\
\hline-45 & 0 & 0 & 0 & 0 & 0 & 0 & 0 & 0 & 0 & 1 & 1 & 1 & 1 & 1 & 1 & 0 & 0 & 0 & 0 & 0 & 0 & 6 \\
\hline-31 & 0 & 0 & 0 & 0 & 0 & 0 & 0 & 0 & 0 & 0 & 0 & 0 & 0 & 0 & 0 & 0 & 0 & 1 & 0 & 0 & 0 & 1 \\
\hline $\mathbf{- 3 2}$ & 0 & 0 & 0 & 0 & 0 & 0 & 0 & 0 & 0 & 0 & 0 & 0 & 0 & 0 & 0 & 0 & 0 & 1 & 0 & 0 & 0 & 1 \\
\hline 3 & 0 & 0 & 0 & 0 & 0 & 0 & 0 & 0 & 0 & 0 & 0 & 0 & 0 & 0 & 0 & 0 & 0 & 1 & 0 & 0 & 0 & 1 \\
\hline $\mathbf{- 3 4}$ & 0 & 0 & 0 & 0 & 0 & 0 & 0 & 0 & 0 & 0 & 0 & 0 & 0 & 0 & 0 & 0 & 0 & 1 & 0 & 0 & 0 & 1 \\
\hline-35 & 0 & 0 & 0 & 0 & 0 & 0 & 0 & 0 & 0 & 0 & 0 & 0 & 0 & 0 & 0 & 0 & 0 & 1 & 0 & 1 & 0 & 2 \\
\hline W-36 & 0 & 0 & 0 & 0 & 0 & 0 & 0 & 0 & 0 & 0 & 0 & 0 & 0 & 0 & 0 & 0 & 0 & 1 & 0 & 0 & 0 & 1 \\
\hline-21 & 0 & 0 & 0 & 0 & 0 & 0 & 0 & 0 & 0 & 0 & 0 & 0 & 0 & 0 & 0 & 0 & 0 & 0 & 1 & 0 & 0 & 1 \\
\hline-22 & 0 & 0 & 0 & 0 & 0 & 0 & 0 & 0 & V & 0 & 0 & 0 & 0 & 0 & 0 & 0 & 0 & 0 & 1 & 0 & 0 & 1 \\
\hline-23 & 0 & 0 & 0 & 0 & 0 & 0 & 0 & 0 & 0 & 0 & 0 & 0 & 0 & 0 & 0 & 0 & 0 & 0 & 1 & 0 & 0 & 1 \\
\hline W-11 & 0 & 0 & 0 & 0 & 0 & 0 & 0 & 0 & 0 & 0 & 0 & 0 & 0 & 0 & 0 & 0 & 0 & 0 & 0 & 0 & 1 & 1 \\
\hline W-12 & 0 & 0 & 0 & 0 & 0 & 0 & 0 & 0 & 0 & 0 & 0 & 0 & 0 & 0 & 0 & 0 & 0 & 0 & 0 & 0 & 1 & 1 \\
\hline E-1 & 0 & 0 & 0 & 0 & 0 & 0 & 0 & 0 & 0 & 0 & 0 & 0 & 0 & 0 & 0 & 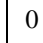 & 0 & 0 & 0 & 0 & 1 & 1 \\
\hline otal & 0 & 0 & 1 & 1 & 0 & 0 & 0 & 0 & 2 & 2 & & 3 & 2 & & 1 & 0 & 0 & 6 & 3 & 1 & 3 & 29 \\
\hline
\end{tabular}

The analysis of Markov chain using probabilities in the effect why the diagram leads to high nurses' attrition rate with the value of 1 . This also validates the effect of Why diagram wherein the final effect is a high nurse attrition rate. 
The Effect-Why diagram (Singh et al., 2017) as in Figure 4 is a static snapshot of the issues that are observed and taken as unidirectional. The effect (E1) is an absorbing state, and so all the Whys lead to it. Once E1 is reached, it would continue to occur till the Why's leading to it are resolved.

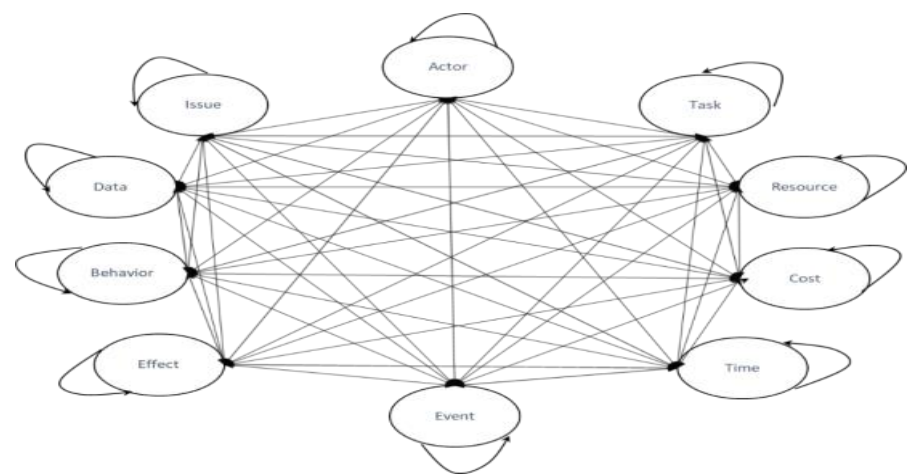

Figure 5 The MEVACTRIBEF Network Diagram

Any change intervention requires a good understanding of the interrelationships and the complexity involved. The network diagram developed named as MEVACTRIBEF as in Figure 5 shows the various interrelationships among Metric $[\mathrm{M}]$, Event [E], Value [V], The Actor [A], Cost [C], Task[T], Resource [R], Issue [I], Behavior [B], Effect [EF.] and each is briefly explained in Table 6. The self-loop arrow shows the recurrence in the operations environment and may not be much seen in the projects environment.

Table 6 The MEVACTRIBEF Measures

\begin{tabular}{|c|c|}
\hline Issue $[\mathbf{I}]$ & $\begin{array}{l}\text { The issue is an undesirable cause or effect and aimed to be eliminated or its effect } \\
\text { minimized in a future state. The issue and result can also be looked as issue pairs. }\end{array}$ \\
\hline Effect $[\mathrm{EF}]$ & $\begin{array}{l}\text { The effect of issues and events that lead to issues. It can also become an issue for } \\
\text { subsequent effects and so on. }\end{array}$ \\
\hline Event $[\mathbf{E}]$ & $\begin{array}{l}\text { These are the undesirable happenings that are taking place in the current state and aimed to } \\
\text { be converted to the desirable happenings in the future state. }\end{array}$ \\
\hline Task $[\mathbf{T}]$ & It is the smallest level of measurable activity taken up for analysis. \\
\hline $\begin{array}{l}\text { Resource } \\
{[\mathbf{R}]}\end{array}$ & It is an entity, person or thing that is utilized to perform a task and has associated cost. \\
\hline Actor $[\mathbf{A}]$ & The individual or entity engaged in performing a task. \\
\hline Value $[V]$ & $\begin{array}{l}\text { It is the quantification of the metric (M). Every metric that is chosen should be measurable } \\
\text { in some form. }\end{array}$ \\
\hline Cost $[\mathrm{C}]$ & It is the expense incurred or budgeted in performing the task. \\
\hline $\begin{array}{l}\text { Behavior } \\
{[B]}\end{array}$ & $\begin{array}{l}\text { These are the undesirable behavior in the current state and need to be changed to a } \\
\text { desirable behavior to a future state. }\end{array}$ \\
\hline Metric [M] & $\begin{array}{l}\text { A metric is a measurement of any task, issue or event. Some values in metric need to be } \\
\text { increased and some reduced in the future state. }\end{array}$ \\
\hline
\end{tabular}


International J. of Opers. and Quant. Management

Table 7 The MEVACTRIBEF Table Corresponding to the Effect-Why Diagram

\begin{tabular}{|c|c|c|c|c|c|c|c|c|c|}
\hline Actor $[\mathbf{A}]$ & Resource [R] & Cost $[\mathrm{C}]$ & Task [T] & Issue [I] & Event $[\mathbf{E}]$ & Metric $[\mathbf{M}]$ & Value[V] & Behaviour [B] & Effect $[\mathrm{EF}]$ \\
\hline $\begin{array}{l}\text { Outpatient } \\
\text { department (OPD) }\end{array}$ & Front office staff & $\begin{array}{l}\text { Departmental } \\
\text { expenses }\end{array}$ & Registration & Poor work environment & $\begin{array}{l}\text { Showdowns } \\
\text { with patients }\end{array}$ & $\begin{array}{l}\text { The average waiting time in } \\
\text { OPD Average complaints per } \\
\text { month }\end{array}$ & $\begin{array}{l}6 \mathrm{~min} / \\
\text { customer } 12\end{array}$ & $\begin{array}{l}\text { Indifferent to patients' } \\
\text { requirements }\end{array}$ & \begin{tabular}{|l} 
Stressful \\
environment for \\
patients
\end{tabular} \\
\hline Doctor ABC & Doctor ABC & $\begin{array}{l}\text { The total cost of } \\
\text { doctor to the } \\
\text { hospital }\end{array}$ & $\begin{array}{l}\text { Diagnosing the } \\
\text { patient }\end{array}$ & Diagnosis not correct & $\begin{array}{l}\text { Emergency } \\
\text { admission }\end{array}$ & $\begin{array}{l}\text { Average consulting time; } \\
\text { Readmission frequency /month }\end{array}$ & 8 min 1 /patient 12 & $\begin{array}{l}\text { Hurrying up in diagnosing } \\
\text { a patient }\end{array}$ & Decreasing trust \\
\hline $\begin{array}{l}\text { Operation Theatre } \\
\text { (OT) }\end{array}$ & $\begin{array}{l}\text { OT doctors and } \\
\text { staff }\end{array}$ & OT expenses & $\begin{array}{l}\text { Cleaning of } \\
\text { the OT }\end{array}$ & $\begin{array}{l}\text { The procedure not } \\
\text { carried out }\end{array}$ & $\begin{array}{l}\text { Hospital- } \\
\text { acquired } \\
\text { infection }\end{array}$ & $\begin{array}{l}\text { OT turnaround time Hospital- } \\
\text { acquired infection frequency/ } \\
\text { month }\end{array}$ & $\begin{array}{l}35 \mathrm{~min} \\
10\end{array}$ & $\begin{array}{l}\text { Lack of seriousness in } \\
\text { meeting the cleaning } \\
\text { requirements }\end{array}$ & $\begin{array}{l}\text { Frequent } \\
\text { readmissions }\end{array}$ \\
\hline $\begin{array}{l}\text { Operation Theatre } \\
\text { (OT) }\end{array}$ & $\begin{array}{l}\text { OT doctors and } \\
\text { staff }\end{array}$ & OT expenses & Surgery & $\begin{array}{l}\text { Unplanned } \\
\text { readmissions }\end{array}$ & $\begin{array}{l}\text { Emergency } \\
\text { admission }\end{array}$ & $\begin{array}{l}\text { Average time in the surgical } \\
\text { category }\end{array}$ & $45 \mathrm{~min}$ & Hurrying up the operations & $\begin{array}{l}\text { Reducing trust in } \\
\text { doctors and hospital }\end{array}$ \\
\hline Nurse & $\begin{array}{l}\text { Administration } \\
\text { department }\end{array}$ & Average cost/nurse & Patient care & $\begin{array}{l}\text { High nurses attrition } \\
\text { rate (E1) }\end{array}$ & Nurses leave & Attrition rate/month & 4 & $\begin{array}{l}\text { Hurrying up work } \\
\text { Reduced empathy }\end{array}$ & $\begin{array}{l}\text { High nurses attrition } \\
\text { rate (E1) }\end{array}$ \\
\hline Nurse & $\begin{array}{l}\text { Administration } \\
\text { department }\end{array}$ & Average cost/nurse & Patient care & $\begin{array}{l}\text { Low nurses morale } \\
\text { (W11) }\end{array}$ & Nurses leave & Attrition rate/month & 4 & $\begin{array}{l}\text { Hurrying up work } \\
\text { Reduced empathy }\end{array}$ & $\begin{array}{l}\text { High nurses attrition } \\
\text { rate (E1) }\end{array}$ \\
\hline \begin{tabular}{|l|} 
Administration \\
Doctors \\
Nurses \\
\end{tabular} & $\begin{array}{l}\text { Administration } \\
\text { department }\end{array}$ & $\begin{array}{l}\text { Average } \\
\text { cost/specialty }\end{array}$ & \begin{tabular}{|l} 
Patient care \\
Surgery
\end{tabular} & Decreasing trust (W12) & \begin{tabular}{|l|} 
Nurses leave \\
Stock-out of \\
essential items
\end{tabular} & $\begin{array}{l}\text { Attrition rate/month } \\
\text { Safety stock }\end{array}$ & $\begin{array}{l}4 \\
3 \text { Weeks }\end{array}$ & stashing of items & $\begin{array}{l}\text { High nurses attrition } \\
\text { rate (E1) }\end{array}$ \\
\hline Nurses & $\begin{array}{l}\text { Administration } \\
\text { department }\end{array}$ & $\begin{array}{l}\text { Average } \\
\text { cost/specialty }\end{array}$ & Patient care & $\begin{array}{l}\text { Less than market } \\
\text { salaries (W21) }\end{array}$ & $\begin{array}{l}\text { Nurses leave } \\
\text { Nurses } \\
\text { complaint }\end{array}$ & $\begin{array}{l}\text { Attrition rate/month } \\
\text { Frequency of complaints/month }\end{array}$ & $\begin{array}{l}4 \\
10\end{array}$ & Rising complaints & $\begin{array}{l}\text { Low nurses morale } \\
\text { (W11) }\end{array}$ \\
\hline Nurses & $\begin{array}{l}\text { Administration } \\
\text { department }\end{array}$ & $\begin{array}{l}\text { Average } \\
\text { cost/specialty }\end{array}$ & Patient care & $\begin{array}{l}\text { Inadequate } \\
\text { infrastructure (W22) }\end{array}$ & \begin{tabular}{|l|} 
Nurses leave \\
Nurses \\
complaint
\end{tabular} & $\begin{array}{l}\text { Attrition rate/month } \\
\text { Frequency of complaints/month }\end{array}$ & $\begin{array}{l}4 \\
10\end{array}$ & Rising complaints & $\begin{array}{l}\text { Low nurses morale } \\
\text { (W11) }\end{array}$ \\
\hline \begin{tabular}{|l|} 
Nurses \\
Doctors
\end{tabular} & $\begin{array}{l}\text { Administration } \\
\text { department }\end{array}$ & $\begin{array}{l}\text { Average } \\
\text { cost/specialty }\end{array}$ & $\begin{array}{l}\text { Patient care } \\
\text { Surgery }\end{array}$ & $\begin{array}{l}\text { Communication is } \\
\text { ineffective (W24 / } \\
\text { W35) }\end{array}$ & \begin{tabular}{|l|}
$\begin{array}{l}\text { Surgeries } \\
\text { delayed }\end{array}$ \\
\end{tabular} & Average delay & $25 \mathrm{~min}$ & $\begin{array}{l}\text { Frustration } \\
\text { Dissatisfaction }\end{array}$ & $\begin{array}{l}\text { Decreasing trust } \\
\text { (W12) }\end{array}$ \\
\hline \begin{tabular}{|l|} 
Nurses \\
Doctors
\end{tabular} & $\begin{array}{l}\text { OT doctors and } \\
\text { staff }\end{array}$ & OT expenses & $\begin{array}{l}\text { Patient care } \\
\text { Surgery }\end{array}$ & $\begin{array}{l}\text { Teamwork is } \\
\text { ineffective (W31) }\end{array}$ & $\begin{array}{l}\text { Incorrect } \\
\text { medicines }\end{array}$ & The first time pass rate & $85 \%$ & $\begin{array}{l}\text { Anxiety } \\
\text { Frustration }\end{array}$ & $\begin{array}{l}\text { Recurring medical } \\
\text { errors (W23) }\end{array}$ \\
\hline \begin{tabular}{|l|} 
Nurses \\
Doctors
\end{tabular} & $\begin{array}{l}\text { OT doctors and } \\
\text { staff }\end{array}$ & OT expenses & $\begin{array}{l}\text { Patient care } \\
\text { Surgery }\end{array}$ & $\begin{array}{l}\text { Teamwork is } \\
\text { ineffective (W31) }\end{array}$ & $\begin{array}{l}\text { Incorrect } \\
\text { medicines }\end{array}$ & The first time pass rate & $85 \%$ & \begin{tabular}{|l} 
Anxiety \\
Frustration
\end{tabular} & $\begin{array}{l}\text { Recurring medical } \\
\text { errors (W23) }\end{array}$ \\
\hline
\end{tabular}


Table 7 (Contd.) The MEVACTRIBEF Table Corresponding to the Effect-Why Diagram

\begin{tabular}{|c|c|c|c|c|c|c|c|c|c|}
\hline Actor $[\mathbf{A}]$ & Resource [R] & Cost $[\mathrm{C}]$ & Task [T] & Issue [I] & Event [E] & Metric [M] & Value[V] & Behaviour [B] & Effect $[\mathrm{EF}]$ \\
\hline \begin{tabular}{|l|} 
Nurses \\
Doctors
\end{tabular} & Ward & Ward expenses & Patient care & $\begin{array}{l}\text { No knowledge sharing } \\
\text { (W32) }\end{array}$ & $\begin{array}{l}\text { Incorrect } \\
\text { medicines }\end{array}$ & The first time pass rate & $80 \%$ & \begin{tabular}{|l} 
Anxiety \\
Frustration
\end{tabular} & Recurring medical errors(W23) \\
\hline Nurses & $\begin{array}{l}\text { OT doctors and } \\
\text { staff }\end{array}$ & OT expenses & $\begin{array}{l}\text { Patient care } \\
\text { Surgery }\end{array}$ & $\begin{array}{l}\text { Data collection non-standard } \\
\text { (W33) }\end{array}$ & Missing data & $\begin{array}{l}\text { Percentage of data collected in } \\
\text { the standard template }\end{array}$ & $60 \%$ & $\begin{array}{l}\text { Anxiety } \\
\text { Frustration }\end{array}$ & Recurring medical errors (W23) \\
\hline \begin{tabular}{|l|} 
Nurses \\
Doctors
\end{tabular} & $\begin{array}{l}\text { OT doctors and } \\
\text { staff }\end{array}$ & OT expenses & $\begin{array}{l}\text { Patient care } \\
\text { Surgery }\end{array}$ & \begin{tabular}{|l} 
Documentation \\
Incomplete (W34)
\end{tabular} & Missing data & $\begin{array}{l}\text { Percentage of data not } \\
\text { captured correctly }\end{array}$ & $20 \%$ & $\begin{array}{l}\text { Anxiety } \\
\text { Frustration }\end{array}$ & Recurring medical errors (W23) \\
\hline \begin{tabular}{|l|} 
Nurses \\
Doctors
\end{tabular} & $\begin{array}{l}\text { OT doctors and } \\
\text { staff Ward }\end{array}$ & $\begin{array}{l}\text { OT expenses Ward } \\
\text { expenses }\end{array}$ & $\begin{array}{l}\text { Patient care } \\
\text { Surgery }\end{array}$ & $\begin{array}{l}\text { Coordination is ineffective } \\
\text { (W36) }\end{array}$ & $\begin{array}{l}\text { Missing data } \\
\text { Surgery delayed }\end{array}$ & The first time pass rate & $80 \%$ & \begin{tabular}{|l|} 
Anxiety \\
Frustration
\end{tabular} & Recurring medical errors (W23) \\
\hline \begin{tabular}{|l|} 
Nurses \\
Doctors
\end{tabular} & $\begin{array}{l}\text { OT doctors and } \\
\text { staff Ward }\end{array}$ & $\begin{array}{l}\text { OT expenses } \\
\text { Ward expenses }\end{array}$ & $\begin{array}{l}\text { Patient care } \\
\text { Surgery }\end{array}$ & $\begin{array}{l}\text { No incentive for sharing } \\
\text { (W41) }\end{array}$ & $\begin{array}{l}\text { Missing data } \\
\text { Surgery delayed }\end{array}$ & The first time pass rate & $80 \%$ & $\begin{array}{l}\text { Anxiety } \\
\text { Frustration }\end{array}$ & $\begin{array}{l}\text { Teamwork is ineffective (W31) } \\
\text { No knowledge sharing (W32) }\end{array}$ \\
\hline \begin{tabular}{|l|} 
Nurses \\
Doctors
\end{tabular} & $\begin{array}{l}\text { OT doctors and } \\
\text { staff Ward }\end{array}$ & $\begin{array}{l}\text { OT expenses } \\
\text { Ward expenses }\end{array}$ & $\begin{array}{l}\text { Patient care } \\
\text { Surgery }\end{array}$ & $\begin{array}{l}\text { No mechanism for sharing } \\
\text { (W42) }\end{array}$ & $\begin{array}{l}\text { Missing data } \\
\text { Surgery delayed }\end{array}$ & The first time pass rate & $80 \%$ & \begin{tabular}{|l} 
Anxiety \\
Frustration
\end{tabular} & No knowledge sharing (W32) \\
\hline \begin{tabular}{|l|} 
Nurses \\
Doctors
\end{tabular} & $\begin{array}{l}\text { OT doctors and } \\
\text { staff Ward }\end{array}$ & $\begin{array}{l}\text { OT expenses } \\
\text { Ward expenses }\end{array}$ & $\begin{array}{l}\text { Patient care } \\
\text { Surgery }\end{array}$ & No data standards (W43) & $\begin{array}{l}\text { Missing data } \\
\text { Surgery delayed }\end{array}$ & The first time pass rate & $80 \%$ & $\begin{array}{l}\text { Anxiety } \\
\text { Frustration }\end{array}$ & Data collection non-standard (W33) \\
\hline \begin{tabular}{|l|} 
Nurses \\
Doctors
\end{tabular} & $\begin{array}{l}\text { OT doctors and } \\
\text { staff Ward }\end{array}$ & $\begin{array}{l}\text { OT expenses } \\
\text { Ward expenses }\end{array}$ & $\begin{array}{l}\text { Patient care } \\
\text { Surgery }\end{array}$ & Fragmented processes (W44) & $\begin{array}{l}\text { Missing data } \\
\text { Surgery delayed }\end{array}$ & The first time pass rate & $80 \%$ & \begin{tabular}{|l|} 
Anxiety \\
Frustration \\
Ignorance \\
\end{tabular} & Documentation incomplete (W34) \\
\hline \begin{tabular}{|l|} 
Nurses \\
Doctors
\end{tabular} & $\begin{array}{l}\text { OT doctors and } \\
\text { staff Ward }\end{array}$ & $\begin{array}{l}\text { OT expenses } \\
\text { Ward expenses }\end{array}$ & $\begin{array}{l}\text { Patient care } \\
\text { Surgery }\end{array}$ & $\begin{array}{l}\text { Limited understanding } \\
\text { (W45) }\end{array}$ & $\begin{array}{l}\text { Missing data } \\
\text { Surgery delayed }\end{array}$ & The first time pass rate & $80 \%$ & \begin{tabular}{|l|} 
Anxiety \\
Frustration \\
Ignorance \\
\end{tabular} & $\begin{array}{l}\text { Teamwork is ineffective (W31) } \\
\text { No knowledge sharing (W32) } \\
\text { Data collection non-standard (W33) }\end{array}$ \\
\hline $\begin{array}{l}\text { Nurses } \\
\text { Doctors }\end{array}$ & $\begin{array}{l}\text { OT doctors and } \\
\text { staff Ward }\end{array}$ & $\begin{array}{l}\text { OT expenses } \\
\text { Ward expenses }\end{array}$ & $\begin{array}{l}\text { Patient care } \\
\text { Surgery }\end{array}$ & Inadequate training (W51) & $\begin{array}{l}\text { Missing data } \\
\text { Surgery delayed }\end{array}$ & The first time pass rate & $80 \%$ & \begin{tabular}{|l|} 
Anxiety \\
Frustration \\
Ignorance \\
\end{tabular} & Limited understanding (W45) \\
\hline $\begin{array}{l}\text { Nurses } \\
\text { Doctors }\end{array}$ & $\begin{array}{l}\text { OT doctors and } \\
\text { staff Ward }\end{array}$ & \begin{tabular}{|l} 
OT expenses \\
Ward expenses
\end{tabular} & $\begin{array}{l}\text { Patient care } \\
\text { Surgery }\end{array}$ & $\begin{array}{l}\text { Priority by perceptions } \\
\text { (W52) }\end{array}$ & $\begin{array}{l}\text { Missing data } \\
\text { Surgery delayed }\end{array}$ & The first time pass rate & $80 \%$ & \begin{tabular}{|l} 
Anxiety \\
Frustration \\
Ignorance \\
\end{tabular} & Limited understanding (W45) \\
\hline $\begin{array}{l}\text { Nurses } \\
\text { Doctors }\end{array}$ & $\begin{array}{l}\text { OT doctors and } \\
\text { staff Ward }\end{array}$ & $\begin{array}{l}\text { OT expenses } \\
\text { Ward expenses }\end{array}$ & $\begin{array}{l}\text { Patient care } \\
\text { Surgery }\end{array}$ & $\begin{array}{l}\text { Training not on priority } \\
\text { (W61) }\end{array}$ & $\begin{array}{l}\text { Missing data } \\
\text { Surgery delayed }\end{array}$ & The first time pass rate & $80 \%$ & \begin{tabular}{|l} 
Anxiety \\
Frustration \\
Ignorance
\end{tabular} & Inadequate training (W51) \\
\hline $\begin{array}{l}\text { Nurses } \\
\text { Doctors }\end{array}$ & $\begin{array}{l}\text { OT doctors and } \\
\text { staff Ward }\end{array}$ & $\begin{array}{l}\text { OT expenses } \\
\text { Ward Expenses }\end{array}$ & $\begin{array}{l}\text { Patient care } \\
\text { Surgery }\end{array}$ & $\begin{array}{l}\text { Limited value measurements } \\
\text { (W62) }\end{array}$ & $\begin{array}{l}\text { Missing data } \\
\text { Surgery delayed }\end{array}$ & The first time pass rate & $80 \%$ & \begin{tabular}{|l|} 
Anxiety \\
Frustration \\
Ignorance
\end{tabular} & Priority by perceptions (W52) \\
\hline
\end{tabular}


Table 7 depicts the MEVACTRIBEF table; detailing the actionable Effect-Why diagram. For example, nurses (Actors) using the administration department (Resource) have an average cost/nurse (Cost) associated with them. The nurses in perform patient care (Task) and have low morale (Issue), which makes them leave (Event). This is measured by attrition rate/month (Metric) and is at 4 (Value). It is seen that nurses are generally hurrying up work (Behavior) and have reduced empathy (Behavior). The outcome of this issue is high nurses' attrition rate.

Table 7 also shows a representation of the current state at a leading tertiary hospital in India as arrived at through discussions with the hospital representatives. It uses several issues listed in Table 2. During the face-to-face interactions with the administration, it was observed that high nurse attrition rate was a major issue or effect and required to be understood for resolving the issues. Further discussions with the hospital administration led to the identification of the multiple causal relationships by use of this table. An application to the effect of high nurse's attrition rate is shown in the Effect-Why diagram. It is to be noted that the description and data are contextual and can be expected to vary as per the hospital under study.

\subsection{Multidirectional Issues Linkages}

In multidirectional issues linkages, there may be different linkages and loops among issues. The Effect-Why diagram now affects and why (cause(s)) at all the levels as shown in Figure 6. The base in the Effect-Why diagram is taken as EW0, and the numbering starts as EW1, EW2 on the upward direction. Here 'high nurse's attrition rate'(EW01) leads to teamwork is ineffective (EW31), low nurses' morale (EW11) and 'high nurses' attrition rate '(EW01) with values as 1/3 each showing one cause and three effects. Here, 'teamwork is ineffective' is both a cause and an effect and so labelled as EW31 for easy identification.

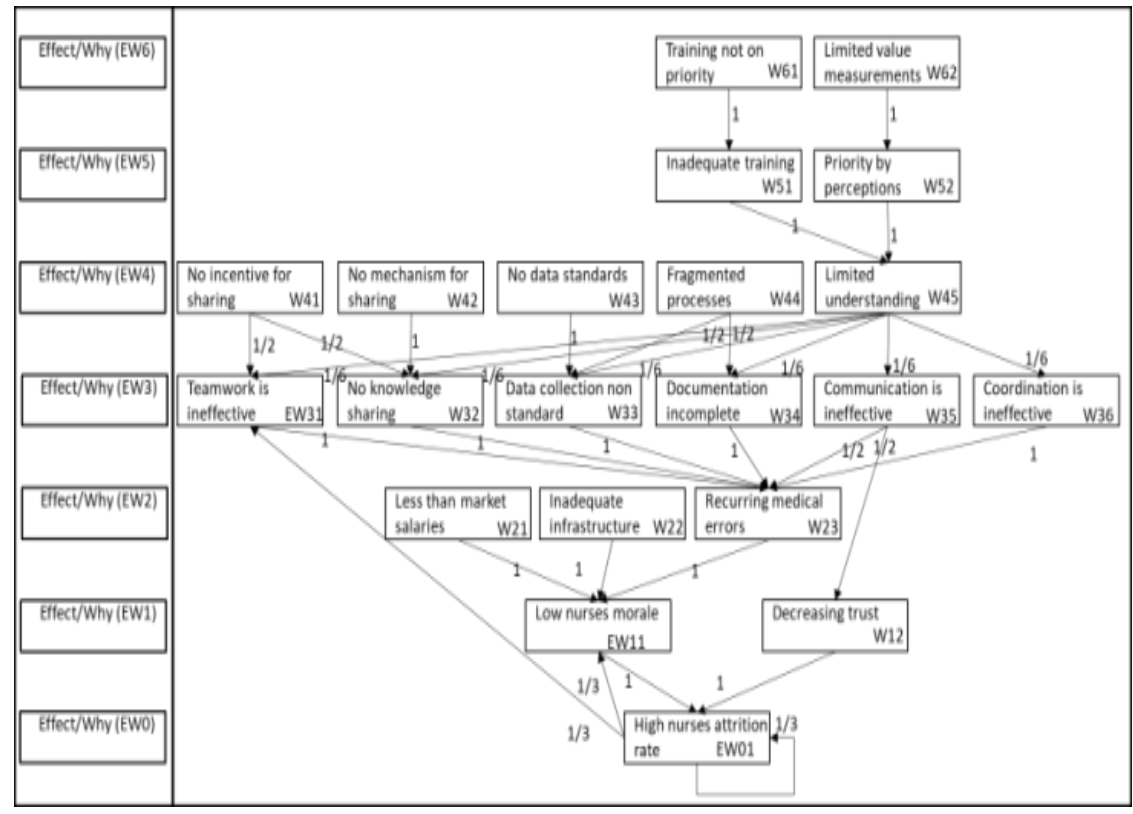

Figure 6 Multidirectional Effect-Why Diagram for a High Nurses Attrition Rate 
The multi-directional issue complexity matrix in Table 8 is for the multidirectional EffectWhy diagram (Figure 6) and shows a higher value of 31 now because of two new linkages that were identified.

Table 8 Multidirectional Issue Complexity Matrix

\begin{tabular}{|c|c|c|c|c|c|c|c|c|c|c|c|c|c|c|c|c|c|c|c|c|c|c|}
\hline & $\begin{array}{l}\text { W- } \\
61\end{array}$ & $\begin{array}{l}\text { W- } \\
62\end{array}$ & $\begin{array}{l}\text { W- } \\
51\end{array}$ & $\begin{array}{l}\text { W- } \\
52\end{array}$ & $\begin{array}{l}\text { W- } \\
41\end{array}$ & $\begin{array}{l}\text { W- } \\
42\end{array}$ & $\begin{array}{l}\text { W- } \\
43\end{array}$ & $\begin{array}{l}\text { W- } \\
44\end{array}$ & $\begin{array}{l}\text { W- } \\
45\end{array}$ & $\begin{array}{c}\text { EW- } \\
\mathbf{3 1}\end{array}$ & $\begin{array}{l}\text { W- } \\
32\end{array}$ & $\begin{array}{l}\text { W- } \\
33\end{array}$ & $\begin{array}{l}\text { W- } \\
34\end{array}$ & $\begin{array}{l}W- \\
35\end{array}$ & $\begin{array}{l}W- \\
36\end{array}$ & $\begin{array}{l}\text { W- } \\
21\end{array}$ & $\begin{array}{l}\text { W- } \\
22\end{array}$ & $\begin{array}{l}\text { W- } \\
23\end{array}$ & $\begin{array}{c}\text { EW- } \\
11\end{array}$ & $\begin{array}{l}\text { W- } \\
12\end{array}$ & E- & Total \\
\hline W-61 & 0 & 0 & 1 & 0 & 0 & 0 & 0 & 0 & 0 & 0 & 0 & 0 & 0 & 0 & 0 & 0 & 0 & 0 & 0 & 0 & 0 & 1 \\
\hline W-62 & 0 & 0 & 0 & 1 & 0 & 0 & 0 & 0 & 0 & 0 & 0 & 0 & 0 & 0 & 0 & 0 & 0 & 0 & 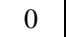 & 0 & 0 & 1 \\
\hline W-51 & 0 & 0 & 0 & 0 & 0 & 0 & 0 & 0 & 1 & 0 & 0 & 0 & 0 & 0 & 0 & 0 & 0 & 0 & 0 & 0 & 0 & 1 \\
\hline W-52 & 0 & 0 & 0 & 0 & 0 & 0 & 0 & 0 & 1 & 0 & 0 & 0 & 0 & 0 & 0 & 0 & 0 & 0 & 0 & 0 & 0 & 1 \\
\hline W-41 & 0 & 0 & 0 & 0 & 0 & 0 & 0 & 0 & 0 & 1 & 1 & 0 & 0 & 0 & 0 & 0 & 0 & 0 & 0 & 0 & 0 & 2 \\
\hline W4-2 & 0 & 0 & 0 & 0 & 0 & 0 & 0 & 0 & 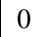 & 0 & 1 & 0 & 0 & 0 & 0 & 0 & 0 & 0 & 0 & 0 & 0 & 1 \\
\hline W-43 & 0 & 0 & 0 & 0 & 0 & 0 & 0 & 0 & 10 & 0 & 0 & 1 & 0 & 0 & 0 & 0 & 0 & 0 & 0 & 0 & 0 & 1 \\
\hline W-44 & 0 & 0 & 0 & 0 & 0 & 0 & 0 & 0 & 0 & 0 & 0 & 1 & 1 & 0 & 0 & 0 & 0 & 0 & 0 & 0 & 0 & 2 \\
\hline W-45 & 0 & 0 & 0 & 0 & 0 & 0 & 0 & 0 & 0 & 1 & 1 & 1 & 1 & 1 & 1 & 0 & 0 & 0 & 0 & 0 & 0 & 6 \\
\hline EW-31 & 0 & 0 & 0 & 0 & 0 & 0 & 0 & 0 & 0 & 0 & 0 & 0 & 0 & 0 & 0 & 0 & 0 & 1 & 0 & 0 & 0 & 1 \\
\hline W-32 & 0 & 0 & 0 & 0 & 0 & 0 & 0 & 0 & 0 & 0 & 0 & 0 & 0 & 0 & 0 & 0 & 0 & 1 & 0 & 0 & 0 & 1 \\
\hline W-33 & 0 & 0 & 0 & 0 & 0 & 0 & 0 & 0 & 0 & 0 & 0 & 0 & 0 & 0 & 0 & 0 & 0 & 1 & 0 & 0 & 0 & 1 \\
\hline W-34 & 10 & 0 & 0 & 0 & 0 & 0 & 0 & 0 & 0 & 0 & 0 & 0 & 0 & 0 & 0 & 0 & 0 & 1 & 0 & 0 & 0 & 1 \\
\hline W-35 & 10 & 0 & 0 & 0 & 0 & 0 & 0 & 0 & 0 & 0 & 0 & 0 & 0 & 0 & 0 & $\sigma$ & 0 & 1 & 0 & 1 & 0 & 2 \\
\hline W-36 & 0 & 0 & 0 & 0 & 0 & 0 & 0 & 0 & 0 & 0 & 0 & 0 & 0 & 0 & 0 & 0 & 0 & 1 & 0 & 0 & 0 & 1 \\
\hline W-21 & 0 & 0 & 0 & 0 & 0 & 0 & 0 & 0 & 0 & 0 & 0 & 0 & 0 & 0 & 0 & 0 & 0 & 0 & 1 & 0 & 0 & 1 \\
\hline W-22 & 0 & 0 & 0 & 0 & 0 & 0 & 0 & 0 & 0 & 0 & 0 & 0 & 0 & 0 & 0 & 0 & 0 & 0 & 1 & 0 & 0 & 1 \\
\hline W-23 & 0 & 0 & 0 & 0 & 0 & 0 & 0 & 0 & 0 & 0 & 0 & 0 & 0 & 0 & 0 & 0 & 0 & 0 & 1 & 0 & 0 & 1 \\
\hline EW-11 & 0 & 0 & 0 & 0 & 0 & 0 & 0 & 0 & 0 & 0 & 0 & 0 & 0 & 0 & 0 & 0 & 0 & 0 & 0 & 0 & 1 & 1 \\
\hline W-12 & 0 & 0 & 0 & 0 & 0 & 0 & 0 & 0 & 0 & 0 & 0 & 0 & 0 & 0 & 0 & 0 & 0 & 0 & 0 & 0 & 1 & 1 \\
\hline EW-01 & 0 & 0 & 0 & 0 & 0 & 0 & 0 & 0 & 0 & 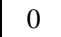 & 0 & 0 & 0 & 0 & 0 & 0 & 0 & 0 & 0 & 0 & 1 & 3 \\
\hline Total & 0 & 0 & 1 & 1 & 0 & 0 & 0 & 0 & 2 & 3 & 3 & 3 & 2 & 1 & 1 & 0 & 0 & 6 & 4 & 1 & 3 & 31 \\
\hline
\end{tabular}

The application of Markov chain in the multi-directional Effect-Why diagram leads to the steady-state probabilities as being teamwork is ineffective $(0.142)$, recurring medical errors (0.142), low nurses' morale (0.284) and high nurses' attrition rate (0.431). The results of unidirectional and multidirectional Markov chain are in Annexure 3. 


\section{Conclusions and Discussions}

The authors have reviewed the literature and integrated areas of data-drivendecision-making and issue-based-decision-making under the overall arch of decisionmaking. Tools for identification and representation of the root issues have been developed. The study is applied to the knowledgebase, and utilized as a starting point for issues identification. The Effect-Why diagrams are shown for the current state to demonstrate their usefulness. The future state Effect-Why diagrams can be drawn in the same way after discussions with the key stakeholders.

As can be seen, by the issues complexity index and the Effect-Why diagram, many issues are required to be resolved for reducing the complexity as well as gaining benefits. As organizational resources are limited, there exists a practical difficulty in addressing all issues simultaneously. The Effect-Why diagram gives a direction to the decision making process by simultaneous display of the issues stream and network. The selection of the issues in a given organizational context and at a given point of time requires decisions to be made.

The MEVACTRIBEF network diagram, the MEVACTRIBEF table and the issue complexity matrix bring out the relationship in visual form and provide value to the degree of complexity. Markov chain, when looked on a standalone, gives limited visibility on the interlink ages and shows the steady-state without providing much understanding of how the states were reached. Using Effect-Why diagram along-with issues complexity matrix and Markov chain, all three provides an enriched understanding of the current state - all the interlink ages that are affecting the transitions. In the unidirectional relationship, the effect (E1) is the stopping point of analysis. The Markov chain is more useful when all issues are connected, and there is no end issue showing the final effect level.

The tools have been applied in the healthcare context for an explanation. There are issues when some things happen, such as late arrival of medical reports cause a delay in surgery and further delays in subsequent surgeries. There are issues when something does not happen, such as not getting appreciated for your contribution. One of the outputs of any patient satisfaction survey could be finding out the percentage of respondents mentioning different issues leading to the identification of key issues requiring resolution.

Resolution of issues is an essential requirement for sustenance unless they exist in a monopolistic organization. Issues affect relationships. The way individuals and institutions handle issues can make or break their reputations. Anger and moral issues are quite frequently seen to cause loss of a person's popularity and growth. Issues are the catalyst for entity creation or individual growth. Issues can cause a change in behaviors, some temporary, some permanent, some forced and some voluntary. Even a small issue like 'error in doctor's prescription' has the potential for significant damage as compared to a small machining error in a finished machine product.

\section{Future Research Directions}

Organizations build their leadership pipeline to develop solution messiahs who are expected continually liberate them from issues that exist now or may exist in future. When issues are resolved, some need or wants either in full or in parts are accomplished. How well it is resolved, needs some metric(s) to be agreed upon when 
planning for resolution. This would require categorization with associated metrics for the outputs or outcomes.

In the paper, equal probabilities of occurrence of effects are taken for explanation and analysis. The method of paired comparison could be, in future, be used to arrive at probabilities based upon their relative importance. The DID Framework could be utilized for integrating the multi-criteria decision-making methods with the machine learning tools for better insights.

Next, an example from the healthcare was taken, as this sector touches and impacts a significant number of people. Researchers and practitioners can explore the applications of the framework and tools in different contexts and environment. These tools can be used across all areas wherein a decision needs to be made.

A process is composed of tasks or activities and can document in various ways. A process can also be discovered from data through process mining applications. Every process may have one or more issue, such as a registration process may have the issue of high waiting time for patients. The issues can be overlaid on the activities of a business process for making decisions on where to make improvements. These steps could be incorporated into any approaches that aim for improvement and excellence.

\section{Acknowledgement}

We are grateful to our reviewers for their valuable suggestions that have made the paper more systematic and instructive. The authors appreciate and thank the hospital administrators who participated voluntarily for discussions from January 2019 to November 2019.

\section{References}

1. Almoaber B, Amyot D. (2017) Barriers to Successful Health Information Exchange Systems in Canada and the USA: A Systematic Review. Int'l J of Healthcare Information Systems and Informatics, 12(1):44-63.

2. Berland A. (2017) Using the Johari Window to explore patient and provider perspectives. Int'1 J of Health Governance, 22(1):47-51.

3. Brooks A, Silverman L, Wallen G. (2013) Shared Decision Making: A Fundamental Tenet in a Conceptual Framework of Integrative Healthcare Delivery. Integrative Medicine Insights, 8:29-36.

4. Booth M, James P, Stevanovic V. (2005) Benchmarking of hospital activity data: an Int'l comparison. Benchmarking Int J., 12(6):515-22.

5. Boulding W, Glickman S, Manary M, Schulman K, Staelin R. (2011) Relationship between patient satisfaction with inpatient care and hospital readmission within 30 days. The American J of Managed Care, 17:41-8.

6. Blumenfeld. Operations Research calculations handbook 2009.

7. Diaby, V., Campbell, K., Goeree, R., 2013. Multi-criteria decision analysis (MCDA) in health care: A bibliometric analysis. Operations Research for Health Care, 2(1/2): 20-24.

8. Dhillon BS (2003) Methods for performing human reliability and error analysis in health care. Int'l J. of Health Care Quality Assurance, 16(6):306-17.

9. Ewing M, Funk G, Warren A, Rapier N, Reynolds M, Bennett M, (2016) Improving National Trauma Data Bank coding data reliability for traumatic injury using a prospective systems approach. Health Informatics J, 22(4):107682. 
10. Gonzalez J, Ferrer J-C, Cataldo A, Rojas L. (2018) A proactive transfer policy for critical patient flow management. Health Care Management Science, 22: 117.

11. He, Staples, Ross, Court. (1996) Fourteen Japanese quality tools in software process improvement. The TQM Magazine, 8(4):40-4.

12. Jagoda K, Lonseth R, Lonseth A. (2013) A bottom-up approach for productivity measurement and improvement. Int'l J Productivity and Performance Management; 62(4):387-406.

13. Morgeson F, Mitchell T, Liu D. (2015) Event System Theory: An EventOriented Approach to the Organizational Sciences. Academy of Management Review, 40(4):515-37.

14. Nooraie M. (2008) Decision magnitude of impact and strategic decision-making process output. Management Decision, 46(4):640-55.

15. Nutt P. (2001) A taxonomy of strategic decisions and tactics for uncovering alternatives. European J of Operational Research, 132(3):505-27.

16. Oliveira, M., Bélanger, V., Marques, I., Ruiz, A., (2020). Assessing the impact of patient prioritization on operating room schedules. Operations Research for Health Care, 24:1-10.

17. Patel V, Abramson E, Edwards A, Cheung M, Dhopeshwarkar R, Kaushal R. (2011) Consumer attitudes toward personal health records in a beacon community. The American J of Managed Care, 17(4): e104-e120.

18. Reddy, B., Walters, S.J., Duenas, A., Thokala, P., Kelly, M.P., 2019. A role for MCDA to navigate the trade-offs in the National Institute for Health and Care Excellence's public health recommendations. Operations Research for Health Care, 23: 100179.

19. Sarkar S, Mukhopadhyay A, Ghosh S. (2013) Root cause analysis, Lean Six Sigma and test of hypothesis. The TQM J, 25(2):170-85.

20. Schonberger R. (2018) Reconstituting lean in healthcare: From waste elimination toward 'queue-less' patient-focused care. Business Horizons, 61(1):13-22.

21. Schwarber P. (2005) Leaders and the decision-making process. Management Decision; 43(7/8):1086-92.

22. Shivakumar R. (2014) How to tell which decisions are strategic. California Management Review, 56(3): 78-97.

23. Singh S, Verma R, Koul S. (2017) Managing critical supply chain issues in Indian healthcare. Procedia Computer Science, 122:315-322.

24. Silva H, Lehoux P, Hagemeister N. (2018) Developing a tool to assess responsibility in health innovation: Results from an Int'l Delphi study. Health Policy Technology, 7(4): 388-396.

25. Stockley A. (1995) Planning and management tools to help with provision of effective health care. Int'1 J of Health Care Quality Assurance, 8(5):24-29.

26. Sorescu A. (2017) Data-Driven Business Model Innovation. The J Product Innovation Management, 34(5):691-696.

27. Song J, Bai Y, Wen J. (2018) Optimal Appointment Rule Design in an Outpatient Department. IEEE Transactions on Automation Science and Engineering,16(1): 100-114. 
28. Langley A, Mintzberg H, Pitcher P, Posada E, Saint-Macary J. (1995) Opening up Decision Making: The View from the Black Stool, Organization Science, 6(3): 241-335.

29. Li L, Chang Q, Ni J. (2009) Data-driven bottleneck detection of manufacturing systems. Int'l J of Production Research, 47(24): 6929-6940.

30. Lucero R, Lindberg D, Fehlberg E, Bjarnadottir R, Li Y, Cimiotti J, (2019) A data-driven and practice-based approach to identify risk factors associated with hospital-acquired falls: Applying manual and semi- and fully-automated methods. Int'1 J of Medical Informatics, 122: 63-69.

31. Myszewski J. (2013) on improvement story by 5 whys. The TQM J, 25(4): 371383.

32. Uriarte, A., Zú-iga, E., Moris, M., Ng, A., (2017) How can decision-makers be supported in the improvement of an emergency department? A simulation, optimization and data mining approach. Operations Research for Health Care, $15: 102-122$.

33. van Veen-Berkx E, de Korne D, Olivier O, Bal R, Kazemier G. (2016) Benchmarking operating room departments in the Netherlands. Benchmarking: An Int'1 J, 23(5): 1171-1192.

34. Wu P-J, Chen M-C, Tsau C-K. (2017) The data-driven analytics for investigating cargo loss in logistics systems. Int'l J of Physical Distribution \& Logistics Management, 47(1): 68-83.

35. Yalcındag S, Matta A, Şahin E, Shanthikumar G. (2016) the patient assignment problem in home health care: using a data-driven method to estimate the travel times of caregivers. Flexible Services and Manufacturing J, 28: 304-335.

\section{Annexure 1: Linkage among the Issues and Decisions}

Table 9 Linkages among Issues and Decisions

\begin{tabular}{|l|l|}
\hline \multicolumn{1}{|c|}{ Linkages } & \multicolumn{1}{c|}{ Description } \\
\hline $\begin{array}{l}\text { Sequential linkages } \\
\text { between decisions }\end{array}$ & Same issue but arising at different times \\
\hline - Nesting & $\begin{array}{l}\text { A decision tree type approach wherein major decision involves the sub- } \\
\text { divisions into minor decisions. }\end{array}$ \\
\hline - Snowballing & A series of minor decisions snowballing into a major decision. \\
\hline - Recurrence & The recurrence of the same decision situation. \\
\hline $\begin{array}{l}\text { Lateral linkages } \\
\text { between the issue }\end{array}$ & $\begin{array}{l}\text { Issues are linked based upon their competition for resources and sharing of } \\
\text { the same organizational context. }\end{array}$ \\
\hline - Pooled & Issues are linked based upon their competition for resources \\
\hline - Contextual & $\begin{array}{l}\text { Issues are linked because they share the same organizational context for } \\
\text { strategy, structure, culture and people. }\end{array}$ \\
\hline Precursive linkages & $\begin{array}{l}\text { The decision on one issue can have a critical effect on other decisions. } \\
\text { These decisions can evoke a new problem or enable the previously blocked }\end{array}$ \\
\hline - Enabling & $\begin{array}{l}\text { A decision may put away blocks to other decisions or make it possible to } \\
\text { attain specific outcomes. }\end{array}$ \\
\hline
\end{tabular}




\begin{tabular}{|l|l|}
\hline - Evoking & A decision may evoke new opportunities or lead to new problems. \\
\hline - Pre-empting & $\begin{array}{l}\text { A decision may delay, make obsolete or take away relevance of other } \\
\text { issues. }\end{array}$ \\
\hline - Cascading & $\begin{array}{l}\text { A decision may have a cascading effect on serially connected decisions } \\
\text { covering a varied range of issues. }\end{array}$ \\
\hline - Merging & Unrelated issues are taken as a single set for making decisions on them. \\
\hline - Learning & $\begin{array}{l}\text { Decisions made in earlier time create learning and affect decisions made at } \\
\text { a later time and different areas. }\end{array}$ \\
\hline
\end{tabular}

\section{Annexure 2: Root Issues Identification Methods}

When faced with an issue, questions need to be asked for identifying the right issue or problem to solve. While some start with the basic questions, the others look at framing the interlink ages of causes and effects.

Several approaches proposed on finding issues at root-cause levels are The sequence of seven circumstances (Myszewski, 2013), The Kepner-Tregoe (K-T) method (Sarkari, 2013), The 5-Why technique (Myszewski, 2013), Root cause analysis (RCA) (Dhillon, 2003), Tree diagram (Stockley, 1995), Cause and Effect diagram (Sarkari, 2013) and the Effect-Why diagram (Singh et al., 2017).

The oldest questioning technique known is by Hermagoras of Temnos (Myszewski, 2013) where in information about an issue is acquired by asking "who (quis), what (quid), when (Quando), where (ubi), why (cur), in what way (quem ad modum) and by what means (quibus adminiculis)". In the K-T method, the RCA seeks both positive and negative questions such as "Who was/was not involved?", "Where it did/did not occur?", "What did/did not happen?" (Sarkari, 2013). The 5Why technique (Sarkari, 2013), another name for Why-Why technique, assumes the cause and effect linkages to be linear. While the root issue is expected to be clear at the fifth Why, there may be some situations wherein clarity could come at a lesser or higher level of Why. The RCA method developed (Dhillon, 2003) by the US Department of Energy is a systematic approach to investigate industrial accidents outlining the adverse event and recording of the important events while moving back in time towards. While developed for a specific purpose, its basic idea has been adopted in various forms.

The Tree diagram shows a similar visual representation to the RCA, although there are different symbols used in making the nodes. The Why-Why diagram or 5-Why diagram assumes a linear relationship between cause and effect. As a non-linear relationship cannot be mapped through the 5-Why diagram, as such, the use of Tree diagram is recommended. Another tool developed by Professor Kaoru Ishikawa in 1943 (Sarkari, 2013) is for organizing the potential causes to a single effect. Known as the Ishikawa chart or fishbone diagram (He and Ross, 1996), it is used as a qualitative tool for summarization of the result obtained from the cause and effect analysis. The right-hand side (the fish head) shows the effect and lists all possible causes on the left-hand side a centrally connected fish spine (Dhillon, 2003).

The Effect-Why diagram is compared with the other well know diagrams on their characteristics for dealing with root cause analysis. 
Table 10 Comparison Table of Effect-Why Diagram Versus other Methods

\begin{tabular}{|c|c|c|c|c|}
\hline Characteristics & $\begin{array}{l}\text { 5-Why } \\
\text { diagram }\end{array}$ & Tree diagram & $\begin{array}{c}\text { Cause and Effect } \\
\text { diagram }\end{array}$ & Effect-Why diagram \\
\hline Linearity & Linear & Non-linear/Branching & Non- linear/Branching & Non-linear/Branching \\
\hline Assumption & $\begin{array}{l}\text { A single } \\
\text { root issue }\end{array}$ & $\begin{array}{l}\text { One or more than one } \\
\text { root issues }\end{array}$ & $\begin{array}{l}\text { One or more than one } \\
\text { root issues }\end{array}$ & $\begin{array}{l}\text { One or more than one } \\
\text { root issues }\end{array}$ \\
\hline \begin{tabular}{|l} 
Root issue \\
identified at a \\
given time
\end{tabular} & One & One or many & One or many & One or many \\
\hline $\begin{array}{l}\text { Effect - Cause } \\
\text { linkages }\end{array}$ & One to One & One to Many & One to Many & $\begin{array}{l}\text { One to One One to Many } \\
\text { Many to One Many to } \\
\text { Many }\end{array}$ \\
\hline Issues grouping & None & Node(s) & Nodes and Branches & Why Levels and issues \\
\hline $\begin{array}{l}\text { Prioritization } \\
\text { requirement }\end{array}$ & $\begin{array}{l}\text { None. The } \\
\text { root issue is } \\
\text { identified. }\end{array}$ & $\begin{array}{l}\text { Yes. Deciding on } \\
\text { whether and which of } \\
\text { the root issues to } \\
\text { resolve first. }\end{array}$ & $\begin{array}{l}\text { Yes. Deciding on } \\
\text { whether and which of } \\
\text { the root issues to resolve } \\
\text { first. }\end{array}$ & $\begin{array}{l}\text { Yes. } \\
\text { Deciding on whether and } \\
\text { which of the root issues } \\
\text { to resolve first. }\end{array}$ \\
\hline Issues Complexity & $\begin{array}{l}\text { Limited } \\
\text { visibility }\end{array}$ & $\begin{array}{l}\text { Visibility to some } \\
\text { degree. }\end{array}$ & $\begin{array}{l}\text { Visibility to a high } \\
\text { degree }\end{array}$ & Higher visibility \\
\hline $\begin{array}{l}\text { Measurements of } \\
\text { interlink ages }\end{array}$ & None & $\begin{array}{l}\text { At the connecting } \\
\text { node of the branches. } \\
\text { Using probabilities for } \\
\text { each branch. }\end{array}$ & $\begin{array}{l}\text { Requires much more } \\
\text { discussions and analysis } \\
\text { for overall } \\
\text { understanding of the } \\
\text { branches. }\end{array}$ & $\begin{array}{l}\text { Using the issue } \\
\text { complexity index. Using } \\
\text { probabilities for each } \\
\text { Effect-Why and Why- } \\
\text { Why linkages. } \\
\text { Direct mapping to } \\
\text { Markov chain }\end{array}$ \\
\hline
\end{tabular}

The authors propose the Effect-Why diagram tool and have demonstrated how its adoption brings out more interlink ages vis-à-vis other well-known tools that are being used.

\section{Annexure 3: Markov Chain Analysis Results for Limiting State}

In Markov chain transitions, the steady-state or limiting state probabilities $\left(\pi_{\mathrm{j}}\right)$ (Blumenfeld, 2009) are calculated using

$$
\pi_{j}=\sum_{i=1}^{n} \pi_{i} P_{i j}(j=1,2, \ldots n)
$$

Where, $\mathrm{n}$ - number of states

$P_{i j}$ - the probability of transition from the state I to state $\mathrm{j}(\mathrm{i}, \mathrm{j}=1,2, \ldots \mathrm{n})$

$\pi_{\mathrm{j}}$ - limiting probability for the state $\mathrm{j}(\mathrm{j}=1,2, \ldots \mathrm{n})$

The same can also be represented in the matrix form as

$$
\pi=\pi \mathrm{P}
$$

Where, $\pi=\left(\pi_{1}, \pi_{2}, \ldots \pi_{n}\right)$ is a row vector of limiting state probabilities $\left(0 \leq \pi_{n} \leq 1\right.$ for all j)

$\mathbf{P}=\left(\mathrm{P}_{\mathrm{ij}}\right)$ is the matrix of all transition probabilities. And

$$
\sum_{j=1}^{n} \pi_{j}=1
$$


Equations 1, 2, 3 were used for calculating the steady-state probabilities using Lingo.18 (LINDO) software

\begin{tabular}{|c|c|c|c|c|c|}
\hline \multicolumn{3}{|c|}{$\begin{array}{l}\text { Markov chain steady-state result } \\
\text { (unidirectional Effect-Why diagram) }\end{array}$} & \multicolumn{3}{|c|}{\begin{tabular}{|l}
$\begin{array}{l}\text { Markov chain steady-state result } \\
\text { (multidirectional Effect-Why diagram) }\end{array}$ \\
(mion
\end{tabular}} \\
\hline W61 & A & SPROB(A)0.000000 & W61 & $\mathrm{A}$ & SPROB (A)0.000000 \\
\hline \begin{tabular}{|l|} 
W62 \\
\end{tabular} & B & SPROB(B) 0.000000 & \begin{tabular}{|l|} 
W62 \\
\end{tabular} & B & SPROB (B) 0.000000 \\
\hline W51 & C & SPROB(C)0.000000 & W51 & $\mathrm{C}$ & SPROB (C)0.000000 \\
\hline W52 & $\mathrm{D}$ & SPROB(D)0.000000 & W52 & $\mathrm{D}$ & SPROB (D) 0.000000 \\
\hline W41 & $\mathrm{E}$ & SPROB(E)0.000000 & W41 & $E$ & SPROB (E) 0.000000 \\
\hline W42 & $\mathrm{F}$ & SPROB(F)0.000000 & W42 & $\mathrm{F}$ & SPROB (F) 0.000000 \\
\hline W43 & G & SPROB $(\mathrm{G}) 0.000000$ & W43 & G & SPROB $(\mathrm{G}) 0.000000$ \\
\hline W44 & $\mathrm{H}$ & SPROB $(H) 0.000000$ & W44 & $\mathrm{H}$ & SPROB $(\mathrm{H}) 0.000000$ \\
\hline W45 & I & SPROB(I) 0.000000 & W45 & $\mathrm{I}$ & SPROB (I)0.000000 \\
\hline \begin{tabular}{|l|} 
EW31 \\
\end{tabular} & $\mathrm{J}$ & SPROB(J) 0.000000 & \begin{tabular}{|l|} 
EW31 \\
\end{tabular} & $\mathrm{J}$ & SPROB (J)0.1422414 \\
\hline W32 & $\mathrm{K}$ & SPROB $(\mathrm{K}) 0.000000$ & \begin{tabular}{|l|} 
W32 \\
\end{tabular} & $\mathrm{K}$ & SPROB (K)0.000000 \\
\hline W33 & $\mathrm{L}$ & SPROB(L) 0.000000 & W33 & $\mathrm{L}$ & SPROB (L)0.000000 \\
\hline W34 & $\mathrm{M}$ & SPROB(M)0.000000 & W34 & $\mathrm{M}$ & SPROB (M)0.000000 \\
\hline W35 & $\mathrm{N}$ & SPROB(N)0.000000 & \begin{tabular}{|l|} 
W35 \\
\end{tabular} & $\mathrm{N}$ & SPROB (N)0.000000 \\
\hline W36 & $\mathrm{O}$ & SPROB $(\mathrm{O}) 0.000000$ & W36 & $\mathrm{O}$ & SPROB $(\mathrm{O}) 0.000000$ \\
\hline W21 & $\mathrm{P}$ & SPROB(P) 0.000000 & W21 & $\mathrm{P}$ & SPROB (P)0.000000 \\
\hline W22 & $\mathrm{Q}$ & SPROB(Q)0.000000 & W22 & Q & SPROB $(\mathrm{Q}) 0.000000$ \\
\hline W23 & $\mathrm{R}$ & SPROB(R)0.000000 & W23 & $\mathrm{R}$ & SPROB (R) 0.1422414 \\
\hline EW11 & S & SPROB(S)0.000000 & EW11 & S & SPROB (S)0.2844828 \\
\hline W12 & $\mathrm{T}$ & SPROB(T)0.000000 & W12 & $\mathrm{T}$ & SPROB (T)0.000000 \\
\hline E1 & $\mathrm{U}$ & SPROB(U) 1.000000 & E1 & $\mathrm{U}$ & SPROB (U) 0.4310345 \\
\hline
\end{tabular}

\section{About Our Authors}

Sudhanshu Singh a consultant-cum-trainer, is pursuing his $\mathrm{PhD}$ in Decision Sciences \& Information Systems at NITIE, Mumbai. He holds an MBA (Intl. Business) from AIT, Bangkok and is a Bachelor of Engineering (Production and Industrial Engineering) from J.N.V University, Jodhpur, India. He is a certified PMP and Six Sigma Black Belt (ASQ). His key strengths are in Business Process Engineering, Quality management, IT Applications for Business, developing elearning modules across multiple industries. While as a Principal Consultant at IL\&FS, Mumbai he has been instrumental for the over planning and logistics for Aadhaar (UID) enrolments and the comprehensive e-Governance System for the Government of Maharashtra. Before that as a Business Consultant with Tech Mahindra, Mumbai and Assistant Director, National Productivity Council, India, each project brought in accolades and improvement to the projects implemented. He has presented several academic and technical papers at Int'l Conferences. His current research interests are in IT implementation in the Healthcare Industry, supply chains, Industry 4.0 and IOT.

Rakesh Verma [Orcid ID: 0000-0002-3637-7788] is an Associate Professor of Operations Management in National Institute of Industrial Engineering (NITIE), Mumbai, India. He received his Doctorate in Operations Research from Indian Institute of Technology, Kharagpur, India. He is a DAAD alumnus. He has to his 
credit more than 35 refereed publications in $\mathbf{J}$ s such as The $\mathbf{J}$ of Fuzzy Mathematics, Fuzzy Sets and Systems, Asia Pacific Journal of Operational Research, Physics and Chemistry of the Earth, Int'l Journal of Soft Computing and Int'l Journal of Business Performance and Supply Chain Modelling. He is a member of INFORMS, USA, POMS, India, ORSI, India and Int'l Society on Multiple Criteria Decision Making, USA. His research interests include facility location; transportation systems; multiple criteria decision-making, fuzzy MCDM and supply chain management.

Saroj Koul [Orcid ID: 0000-0002-3051-5625] is a Professor of Supply Chain Management at the Jindal Global Business School, India. Her industry, teaching and research experience spans 35 years. She has to her credit over 45 refereed publications and two books for postgraduate management students. She was recipient of Research Achievement Awards (2011-2013, 2017-18, 2018-19) and Teaching Excellence Awards (2012, 2014, 2018 and 2019). She is also the beneficiary of several SME research funding where the application of 'Balanced Scorecard' and 'Strategic Orientations of Manufacturing Strategy' within Indian MSME's is being researched.She is on the editorial board of J.of Business Ecosystem, J.of Business and Finance Research, AIMS Int'l J.of Management, Int'l J.of Agriculture Innovations, Technology and Globalization, Emerald's Emerging Markets Case Studies Collection. Her research focuses on system dynamics models, supply chain management, SMEs and organizational communication. 